\title{
Presidential Power Unbound: A Comparative Look at Presidential Pardon Power
}

\author{
Jody C. Baumgartner \\ International College in Beijing
}

Mark H. Morris

Miami University

Though few scholars compare presidencies, a recent collection by John Carey and Matthew Shugart (1998) compares the use of the presidential executive decree power in several countries. In a similar vein, we examine the oft-neglected power of the presidential pardon in the United States and Russia. The power of presidents to grant pardons is typically unlimited, which fact alone makes it worthwhile to understand. Like Carey and Shugart, we look at the institutional factors involved in the potential and actual use of the pardon power in our attempt to explicate the foundations of and the constraints on presidential pardons, as well as any trends which may be evident in its use. The comparison highlights the difficulties in precisely defining "pardon," as well as illustrating the fact that this seemingly minor power in a newer democracy can be used as a powerful political tool.

Just five days after his impeachment by the House of Representatives, President Bill Clinton issued executive pardons to 33 United States citizens. These citizens had their records cleared and their civil rights restored, joining 77 others who had previously received pardons or commutations from Clinton. The power of a president to grant pardons is typically broad and without significant constraints. This fact alone, in an era of constitutional government wherein different branches of government can check each other's powers, makes it worthwhile to understand. However, the pardon power is little studied and little understood. What is the basis of the power? What boundaries are established to prevent abuse or misuse? In short, what do we know about it?

In this paper we look at the power of presidential pardons in the United States and Russia. Following a recent example by John Carey and Matthew Shugart (1998) who compare the conditions and use of the power of

Politics \& Policy • Volume $29 \cdot$ No.2 • June 2001 
executive decree, we look at the presidential power to pardon in the United States and Russia. The study is largely a descriptive effort designed to contribute to a very small body of knowledge on comparative presidential power. We first present a brief overview of comparative presidential literature and then discuss the framework and the pardon power in general terms. Following that, the cases are presented.

The cases of the United States and Russia have been chosen because they provide an interesting contrast between the fairly routinized use of the pardon power in a well established democracy (the United States) and the struggle to control the pardon power in a newly emerging democratic state (Russia). The conclusions point to important similarities as well as differences between the two cases. In both countries, the power to pardon is relatively unchecked by other branches of government and has been a useful means of quieting political unrest. The two cases diverge with respect to the control of the pardon power, partially rooted in a blurry distinction between pardons and amnesties, which is probably related to political development.

\section{Comparative Presidential Scholarship}

Few political scientists compare presidencies, and fewer still compare presidential powers. As Riggs (1988; King 1993) noted, for some reason comparativists typically do not consider the case of the United States to be worthy of their attention, while Americanists likewise are reluctant to compare their case to others. The U.S. is considered to be, implicitly or otherwise, incomparable. Most presidential scholarship examines system performance and operations. Lijphart's (1992) edited collection is an early but outstanding overview of this scholarship. Similarly, the "presidentialism versus parliamentarianism" debate, spawned by Linz's 1990 work, studies the effects of presidential government on democratic consolidation, system stability, rigidity, legitimacy, effectiveness, and the development of a mature party system. In this debate, presidentialism is typically found wanting in one or more of the above characteristics (Linz and Valenzuela, 1994; O'Donnell, 1995; Stepan and Skach, 1996; Baylis, 1996; Przeworski et al., 1997), but this conclusion is far from universal (see Shugart and Carey, 1992).

In most of these studies, presidentialism is treated as an independent variable, but a few scholars have begun to take presidentialism as a 
Presidential Power Unbound 211

dependent variable, the object of study itself. Frye (1997), for example, looks at the "politics of constitutional choice," specifically, why most postcommunist countries have opted for a presidential or semi-presidential system. Although limited to post-communist presidencies, Taras (1997) and Colton and Tucker (1995) have made promising beginnings in the realm of comparing individual presidencies. A few scholars have moved into the realm of comparing the institutional aspects and actual use of presidential powers, with an eye toward measurement (Lucky, 1993; MacGregor, 1994; Strøm and Neto, 1999). Caution must be used here. As Elster (1997) noted, creating quantitative indices of presidential power entails several problems, specifically that (1) the indices created may be neither reliable nor valid; (2) political practice may not coincide with constitutional text; and (3) indices do not measure presidential power relative to other institutions.

Carey and Shugart's (1998) collection avoids these problems by focusing on a single aspect of presidential power-executive decree power-looking not only at constitutional but other institutional aspects of presidential power as well and comparing these to actual use. It is one of the very few scholarly works that compares a specific aspect of the elusive notion of presidential power.

\section{The Research Approach}

This study borrows loosely from Carey and Shugart's framework, modifying it to better reflect an interest in executive pardon power. The following five factors establish a common framework for our analysis of executive pardon power in the United States and Russia.

- Drafting the Constitution: Is an executive pardon power established?

- $\quad$ Nature of the Executive Pardon: How is an executive pardon granted?

- Constitutional Amendments: How easy is it to amend the constitution?

- Judicial Review: Can the judicial branch review and overturn an executive use of the pardon power?

- Legislative Action: Can the legislature override an executive pardon? Does the legislature have a comparable pardon power? 
The first two factors establish the constitutional and administrative foundations from which executive pardons are requested and granted. The other three factors are potential constraints on the use of presidential pardon power. Other variables that may have theoretical significance - for example, public opinion and/or age of the political system - will momentarily be excluded in order to keep the examination more straightforward. In other words, this is an analysis of the strictly formal factors of executive pardon power.

\section{Pardons}

The power to pardon has a long and interesting history. The power to pardon first appeared in the oldest known legal code, the Code of Hammurabi which dates to the eighteenth century B.C. (Moore 1989). While the King of England had exercised the power to pardon for centuries, the power did not appear in coded law until the seventh century (Moore 1989). Over time, the power to pardon emerged as a check on developing judicial systems that were often harsh and unforgiving. Sentences that were deemed unfair or unjust could be moderated through an act of executive clemency.

While one may idealistically view the pardon as a tool for justice and mercy, we should not overlook the practical use of this power for political gain. Kings of England used the power to pardon to generate revenuethrough selling pardons - in order to raise armies of beholden pardon recipients and even to create a labor force to be shipped off to the new world (Moore 1989). While the modern day understanding and use of pardon power is more often associated with notions of mercy and fairness, this analysis will demonstrate that it also remains squarely in the political arena.

Called pardons, amnesties, clemency, "grace" (as in, for example, Monaco), or mercy (as in Sweden), the pardon power is included in the written constitutions of nearly all countries. Moreover, pardons are an established part of modern politics. Some pardons attract a great deal of attention. In June 2000, Italian President Carlo Ciampi pardoned Mehmet Ali Agca, a man jailed for his attempt to murder Pope John Paul II in 1981(Naravane 2000). French President Jacques Chirac rejected a pardon request by 89 year old Maurice Papon, a former official in the Vichy regime convicted of "complicity in crimes against humanity" in a highly publicized trial in 1998 (August 2000). Other pardons seem fairly routine. On his seventieth birthday, King Hassan II of Saudi Arabia granted various pardons 
Presidential Power Unbound 213

to over 1,800 people. He grants such multiple pardons - as do other heads of state-with some regularity, typically to mark national or religious holidays (“King Grants Pardon to 1,807 Convicts," July 9, 1999).

In most countries, the pardon power is vested in the political executive, and in those countries with a president, this means the president. As of 1998, 32 of the 46 independent states in Europe have presidents. In all of these countries which mention the power to pardon in their constitution (31), the power resides with the president. ${ }^{1}$ In 19 of these countries, the president does not share the power with any other institution of government, nor is the power subject to any other constitutional conditions. Perhaps tellingly, 14 of these presidents are selected by way of direct election. In 12 countries, the president shares the power, or it is subject to other constitutional conditions. Of these, six are electorate-selected presidents and six are parliament-selected.

It is less surprising to find that presidents have the power to pardon than to find this presidential power circumscribed by various institutional means. Generally speaking, newer constitutions place some checks on presidential pardon power (Lucky 1993). This is in line with a recent trend toward "semi-presidentialism" in Europe, toward systems with a dual executive or a prime minister and a president (Strøm and Neto 1999).

At this stage, the analysis should clarify what is meant by pardon. Humbert identifies ten types of clemency or pardon available to executives. This analysis groups these into three categories:

- Modification of Punishment - reprieves, commutations, commutations on condition, and remission of fines and forfeitures;

- $\quad$ Pardon - full pardons, pardons to terminate sentence and restore civil rights, pardons to restore civil rights, and conditional pardons; and

- Amnesty - amnesties and amnesties on condition (Humbert 1941, 22).

"Modification of punishment" is self-explanatory. Although presidents issue occasional commutations, generally speaking, the evolution of the judicial system including paroles has reduced the need for presidential exercise of this type of pardon power. "Pardons", as such, are typically used to remedy acts by individuals against ordinary laws. For example, an 
executive may grant a full pardon to an individual who is thought to have been wrongly convicted and thus remedy an "unjust" punishment. Most of this type of pardon activity consists of either full or conditional pardons.

The third category, "amnesty", is a bit vexing. Scholarship on jurisprudence suggests that there are two general rules by which one can distinguish between a pardon and an amnesty. First, "amnesties normally apply to classes or categories of persons." Secondly, while a pardon typically serves to remit an offense, "an amnesty may be invoked before a criminal proceeding has commenced or at virtually any stage thereafter" (Barry 1994, 442). However, exceptions exist in actual use to both distinctions. As to the first, while amnesties are granted to groups of people rather than to single individuals, the individuals that make up the group share a common offense, e.g., deserters from military service. ${ }^{2}$ With regard to the second distinction, President Ford's pardon of Richard Nixon was a notable exception, an example of a pardon in a pre-conviction situation.

In reality, there is little functional difference between a pardon and an amnesty. Both serve to remove the effects or consequences of a completed or pending criminal conviction. Thus, amnesties must be included in the discussion, not only because the distinction between them and pardons is blurry at best, but more importantly because the use of this power by legislatures is a potential check on the presidential pardon power. For this reason, this analysis distinguishes between "executive pardons" and "legislative amnesties".

\section{The Case of the United States}

Article II, Section 2, of the United States Constitution states in part: "The President . . . shall have power to grant reprieves and pardons for offenses against the United States, except in cases of impeachment." This assessment of the constitutional foundations of the presidential pardon briefly reviews the record of the Constitutional Convention of 1787. Neither of the plans that provided the framework for the constitutional debate- - the New Jersey and Virginia Plans - included a provision for pardoning in their original drafts, but both included it in their revised versions. The basic arguments surrounding the pardon power can be reduced to three primary questions. First, should the power to pardon be formally established? Second, if established, where should the power reside? Third, once located, what, if any, checks should be included? The inclusion of the pardon power 
Presidential Power Unbound 215

in revised drafts suggests that the first question was answered affirmatively, and with little debate. Alexander Hamilton astutely noted in Federalist 74 that "in seasons of insurrection or rebellion, there are often critical moments, when a well-timed offer of pardon to the insurgents or rebels may restore the tranquility of the commonwealth."

The second and third questions did generate debate and are of fundamental importance in understanding the pardon power. John Rutledge added a clause to the Virginia Plan that located the pardon power with the executive (Humbert 1941). Hamilton argued the merits of this in Federalist 74 , writing, "It is not to be doubted, that a single man of prudence and good sense is better fitted, in delicate conjunctures, to balance the motives which may plead for and against the remission of the punishment, than any numerous body whatever."

While the three issues discussed above were important determinants of the final assignment of the pardon with the executive, they also reflect the large-vs-small state debate over the powers of the presidency. With respect to the pardon power, the large states prevailed in their preference to create a stronger president. Having established the pardon power and locating it with the executive, the Framers turned to the question of checking or limiting it. One option considered was a requirement for Senate consent, but Hamilton's argument seemed to carry the day, and such a requirement was not added. A related matter concerned timing: when could a pardon be granted? Some felt the pardon should be limited to post conviction only, but James Wilson countered by suggesting that a pardon might be helpful in obtaining incriminating evidence or testimony against alleged crimes (Humbert 1941). In the end, this argument was persuasive.

Thus, the pardon power emerged from the Constitutional Convention vested as a power exclusive to the president, with no requirements for consent from another branch of government. Full discretion was also provided to the president as to the timing and merits of the pardon grant. As with other provisions of the Constitution, except for the impeachment exclusion, the Framers were very general in their draft and omitted any specifics regarding the definition and use of the pardon power, the use and understanding of which would evolve over time.

While assigning the authority to grant pardons to the president, the Constitution was silent on the administration of this executive power. For nearly a century the administration of pardons was not assigned to a specific executive office or position. In 1865, the office of Pardon Clerk was 
established to manage the administration of the pardon process for the president. This office was replaced with the Attorney in Charge of Pardons in 1892. The Office of the Pardon Attorney (OPA), under the supervision of the Attorney General, is now responsible for administrating the pardon process. Roger C. Adams currently heads the OPA serving as the sixteenth Pardon Attorney in U.S. history. Today's OPA is staffed by approximately 14 employees, including attorneys, paralegals, and support personnel. ${ }^{3}$

Section 28 of the United States Code of Federal Regulations includes the executive clemency regulations that guide the administration of the pardon power, specifying the process and requirements used for the submission, review, and determination of most pardon requests. The code sets forth eligibility requirements for petitioners - typically a five-year waiting period, submission of information on the individual, the crime, and the reason(s) for the pardon request. The OPA may also request that the Federal Bureau of Investigation conduct an investigation. Then, they review the completed package and make a recommendation to the president, who has final authority in the granting or denial of the pardon request. No response from the president within 30 days of a recommended denial is considered concurrence. Finally, all petitioners are notified in writing whether or not their request has been granted. It is important to note that the process used to administer presidential pardons is "advisory and for the internal guidance of the Department of Justice personnel" (28 CFR 1.10). The president has full constitutional authority to act without this or any other process. Richard Nixon's pardon by Gerald Ford did not go through this process.

The Office of the Pardon Attorney maintains a record of all actions taken by that office and has compiled a record dating back to 1900 . It includes the number of pardons and commutations granted by each president each year. For both Presidents George Herbert Walker Bush and William Jefferson Clinton, OPA provides a list of all recipients, the type of relief granted (pardon or commutation), the date of the action, and the offense for which the person was pardoned. What is notably lacking in all of the data supplied by the Office of the Pardon Attorney is the reason(s) for executive clemency. ${ }^{4}$

The Pardon Attorney's data ${ }^{5}$ can be sorted and categorized in a variety of ways. Approximately 75,350 pardon and commutation requests have been processed by the OPA since 1900 . Of that number, 20,089 requests13,763 pardons and 6,326 commutations - have been granted. Democratic 
Presidential Power Unbound 217

presidents have used the clemency power with greater frequency than have Republicans. Since 1900, Democratic presidents averaged 238 actions per year, while Republican presidents averaged 169 actions per year. Unsurprisingly, President Franklin Roosevelt leads all presidents with 3,687 clemency actions; he held office for nearly twelve years. However, his average of 314 clemency actions per year falls below the averages of both President Wilson (344/year) and President Coolidge (326/year).

One interesting trend that emerges from the data is the steady decline in the number of pardon actions granted by more recent presidents. Since 1900 , the average number of pardons and commutations granted per year is 201, but since the presidency of Lyndon Johnson, the average number of presidential pardon actions taken each year has declined. This decline was most precipitous between Carter (142/year) and Reagan (51/year). The elder Bush further reduced the average with just 18 actions per year. Clinton's average of 54 per year is slightly above Reagan's average but still remains well below the 201 annual average overall.

President Clinton's eleventh hour pardons attracted considerable attention from Congress, the press, and the public. In terms of numbers, Clinton's late-term pardons in December and January were approximately equal to the number of pardons granted over the previous seven years. While the particulars of this controversy are interesting and merit further discussion, they are well beyond the scope of this work. However, one of the primary questions raised during this controversy, the question of limitations on presidential pardon power, will be addressed.

One measure of presidential power is the ability to check or alter that power. This section assesses the means of checking pardon power in the United States through the constitutional amendment process, judicial review, and legislative action.

Constitutional Amendments. One fundamental way in which the president's power to pardon could be checked would be to amend the Constitution. Such an amendment of the power could conceivably take the form of eliminating pardons; placing the power in other hands, e.g., the legislature; modifying it to require approval by another government body, e.g., a constitutional court; or setting conditions or qualifications for pardons.

Article V of the United States Constitution establishes a clear, though difficult process for amending the Constitution. Supermajorities are required to both propose and ratify amendments to the Constitution. The passage of 17 amendments excluding the Bill of Rights in over 210 years suggests just 
how difficult the process is. While President Ford's pardon of Richard Nixon resulted in general public outrage, the presidential power to pardon itself remained intact. With little public interest in or understanding of this presidential power, there is no reason to expect any significant change in the foreseeable future. Thus, as a potential check on pardon power, constitutional amendments are very limited.

Judicial Review. The United States' constitutional system creates a three-branch structure of government with separated powers. Within this structure, the United States Supreme Court is the final arbiter of constitutional disputes. In this role, the Court has had a significant impact in establishing the constitutional boundaries of the pardon power. Through a series of cases beginning in 1833, the Court has provided clarity where the Constitution was vague. In brief, the Court has determined that:

- The president may issue conditional or full pardons (Wells 1855).

- The president may issue pardons before, during, or after conviction (Garland, 1867).

- No specific charges need be filed prior to the issuance of a pardon (Burdick v. United States, 1915).

- Recipients cannot reject a presidential pardon (Biddle $v$. Perovich, 1927). ${ }^{6}$

Judicial challenges can and have served to expand rather than to limit the use and scope of presidential pardoning power. Judicial challenges can and have been brought against specific pardon grants, and many have worked their way through the federal judicial system. For example, the constitutionality of President Ford's pardon of Richard Nixon was unsuccessfully challenged in United States District Court (Murphy v. Ford, 1975). But generally speaking, it can be argued that judicial review has defined the power to pardon as virtually absolute. Noting only the impeachment exception, Chief Justice William Howard Taft explicitly confirmed this in Ex parte Grossman (1924).

Legislative Action. In Federalist 74, Alexander Hamilton, especially concerned with a legislative body under public pressure, made his case against congressional involvement in the pardon process. For this reason, the Framers deliberately located the pardon power with the executive and not with Congress. Unlike the judicial branch, Congress has no direct check 
Presidential Power Unbound 219

on the specific use of the pardon power. That is to say, individual pardon grants cannot be overturned by an act of Congress. Congress could theoretically propose a constitutional amendment to alter or abolish the pardon power; but the difficulties associated with this task were noted above. Indirectly, members of Congress can pursue grievances through the judicial process; this may or may not yield the desired results. Another indirect method of challenging the pardon power might be to "go public" in hopes of deterring the president from using the power. For example, this approach was used in attempts to discourage President Clinton from pardoning anyone associated with the Whitewater investment scandal. The effectiveness of this approach is questionable, particularly with a late-term, lame-duck president who is relatively immune from public pressure.

The constitutional amendment process is cumbersome. Congress has no formal say whatever in the process, and the Supreme Court has served to expand the power to the point where it is virtually absolute. Formal checks on presidential pardon power in the United States are weak and pose no serious threat to its use or scope. This weakness is a function of the design and interpretation by the Supreme Court of the U.S. Constitution and the separation of powers it creates.

\section{The Case of Russia}

As alluded to earlier, the United States is not unique in singularly vesting the power to pardon in the top executive. However, a more ambiguous situation prevails in Russia. Since 1993, there have been several extremely high-profile and controversial cases where legislative amnesties, not presidential pardons, were granted. Since a few of these amnesties constituted a positive check on presidential power, they will be discussed here. This section reviews the three formal ways in which checking presidential pardon power in Russia might be accomplished.

Russia inherited a mixed legacy with respect to the constitutional foundation of pardons and amnesties, but like other countries, the power to pardon generally resided with the executive. ${ }^{7}$ The present Russian Constitution dates to December 1993. In order to keep pace with the many political changes in the Soviet Union in the mid-1980s, literally hundreds of amendments had been made to the Soviet-era Constitution from 1978 to 1990. By 1990, it was obvious that a new constitution was needed; from 1990 until 1993, several groups produced draft constitutions. In most, the 
power to pardon was vested in the office of the presidency, and amnesty was delegated to a two-house legislature (Barry 1994, 446-47).

Many contentious issues were at stake in drafting and adopting a new constitution in Russia, e.g., federal relations within the Republic, land ownership, and privatization of the economy. But, the struggle for power between a reactionary Supreme Soviet elected under Soviet rules and President Yeltsin was dominant. Negotiations over the new constitution faltered by mid-1993 and by the end of the summer had broken down completely. On September 21, Yeltsin disbanded the legislature and decreed that elections and a referendum to ratify his draft constitution were to be held in December. The military was called in to enforce this decree on October $4 .{ }^{8}$ On December 12, 1993, Russians went to the polls and ratified the constitution, ${ }^{9}$ fairly labeled "Yeltsin's" Constitution since the legislature had no formal role whatever in drafting, debating, or ratifying it (White et al., 1997, 98-106).

Debate over the Russian Constitution centered mostly on its superpresidential nature (Holmes 1993; Fish 1997). Perhaps because of thisand/or the legacy of Russia's 1000-year autocratic history-it seems that neither the establishment of the power to pardon nor the granting of it to the president were subject of much debate. Article 89[c] of the Russian Constitution states simply that "the President of the Russian Federation shall grant pardons." There are no constitutional restraints on this power.

In spite of the fact that detailed data on the administration of pardons in Russia are not widely available, outlines of pardon administration in Russia are accessible. Since 1992, Russia has had a 15-member Presidential Pardon Commission (PPC) headed by 65-year old novelist Anatoly Pristavkin, a fairly remarkable tenure given Yeltsin's penchant for changing government personnel. In addition to jurists, the Commission includes prominent artists and writers (Reynolds 1998), and it is responsible for reviewing and submitting to the president their recommendations for all pardon requests. Yeltsin reportedly followed these recommendations fairly closely (Gray 1998).

Several fairly high-profile pardon cases in Russia have captured the attention of the Western press in the past few years. For example, two professional hockey players who had defected during the Soviet era to the United States were pardoned by President Yeltsin in October 1994 in order to participate in a charity hockey tournament in Russia (New York Times, October 29, 1994). In October 1997, he pardoned a former Russian diplomat 


\section{Presidential Power Unbound 221}

convicted of spying for the Central Intelligence Agency; this case was notable because it was the first time a convicted spy was set free rather than executed (Philps 1997).

However, until 1999, much of the PPC's work dealt with requests for commutation of death sentences, as many as 10 per week (Reynolds 1998). Table 1 shows pardon and execution statistics for 1991 through 1995. It shows relatively few executions relative to pardons prior to 1995, consistent with the PPC and Yeltsin opposition to the death penalty.

Table 1.

Death Penalty Statistics in Russia, 1991-95

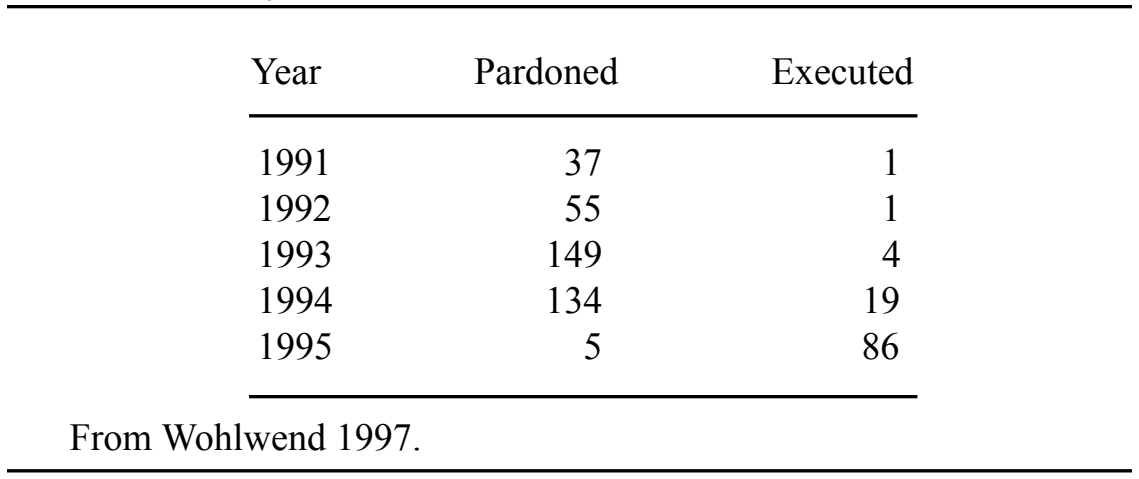

Russia's 1996 membership in the Council of Europe required that they abolish the death penalty by early 1999 . This was problematic, since the overwhelming majority (90 percent) of the Russian population - and the Duma - opposed such a move (Gray 1998). This may be understandable considering that Russia has seen a dramatic increase in organized and violent crime since the breakup of the Soviet Union. In what was clearly an election year strategy to demonstrate he was tough on crime, Yeltsin allowed roughly 130 executions in 1995 and 1996 (Charlton 1999). By way of protest, the PPC suspended its activities (Reynolds 1998). There were no pardons of death row prisoners in the first half of 1996 (Wohlwend 1997).

In August 1996, Yeltsin, safely elected, turned his attention toward compliance with Council of Europe requirements. He ordered a moratorium on executions and promised to abolish the death penalty. Although the death penalty remained on the books and Russian courts continued to issue death 
sentences, most reports suggest that the moratorium was observed (Open Media Research Institute [OMRI], December 17, 1996). ${ }^{11}$ For example, in 1998 Yeltsin commuted roughly 250 death sentences (Halperin 1999). In January 1998, the Duma passed an amendment to the criminal-procedural code giving the president the right to review all death sentences, even for those who had not asked for a presidential pardon (OMRI, January 13, 1998). Thus, the power of the president to pardon - and by extension, the PPC - was increased. In February 1999, Russia's Constitutional Court "banned Russia's courts from imposing death sentences" (Halperin 1999). In June, Yeltsin agreed to the recommendation of the PPC and issued an executive decree commuting death sentences for the more than 700 convicts on death row to life sentences or 25-year prison terms, an action not unlike an amnesty (OMRI, June 3, 1999).

Perhaps the most notorious pardon in Russia's short democratic history was indirect and came on January 1, 2000, the day after President Yeltsin resigned. In one of his first official moves after assuming the position of acting president, Vladimir Putin signed an executive decree granting Yeltsin "and future Russian presidents immunity from criminal prosecution, arrest, search, or interrogation" (OMRI, January 3, 2000). The effect, of course, was a full pardon for Yeltsin. In addition to allegations about criminal wrongdoing (see OMRI, especially in 1999), Yeltsin probably had some concerns over attempts by Communist deputies to prosecute him for breaking up the Soviet Union (Renfrew 2000). Although the timing of the resignation/pardon was seen as part of a deal to "entice Yeltsin into early retirement" (Belin, 2000; Renfrew 2000), it had far more to do with Putin's popularity and the electoral advantage the presidency would give him. This move certainly invites comparison with President Ford's pardon of Nixon in 1974. The pardons of Yeltsin and Nixon, while inexcusable to some, arguably were astute political decisions in the name of social and political stability. Both Ford and Putin had interests in moving forward with their country's agendas and thus had an interest in dealing with their respective predecessors expeditiously. Timely pardons served their purposes well.

There are three ways in which checking presidential pardon power in Russia might be accomplished. These are through constitutional amendments, judicial review, or by legislative action.

Constitutional Amendments. Amending the Russian constitution is difficult. An amendment must garner a two-thirds majority in the Duma, a three-quarters majority in the upper house Federation Council, and then 
Presidential Power Unbound 223

receive the support of two-thirds of the 89 Russian regions. If this were not a high enough barrier, Russia-like many other, newer, free-market democracies - is facing a host of pressing political, social, and economic problems, and there is precious little consensus as to how to go about solving them. Many minority critics including the Communist Party would like to see the president's powers curbed or the presidency abolished altogether. Changing the pardon power does not seem to be high on anyone's agenda. In short, a constitutional amendment dealing with the presidential pardon power is highly unlikely in Russia, at least in the near future.

Judicial Review. The whole notion of judicial review is new to Russia (Dore 1995, 698-701). An independent judiciary was established in Russia for the first time in 1991; prior to this, "socialist legal tradition ... denied a vigorous role to the judicial branch" (Dore 1995, 698). Valery Zorkin, chairman of the first Constitutional Court of democratic Russia, was indeed a vigorous political figure. He was hardly the politically neutral type of justice to which citizens in the United States are accustomed. He was, in fact, very active during the events of October 1993, declaring, even though unbidden, that Yeltsin's closure of parliament was unconstitutional and was promoting his own solution to the crisis. Yeltsin's reaction was to suspend the activities of the Court.

The new constitution revived a Constitutional Court, comprised of 19 judges who serve twelve-year terms. They are appointed by the upper house Federation Council, following nomination by the president. The Court has the power to review presidential decrees, legislative acts, and other laws and is allowed to interpret the Constitution "upon petition" from the "President, the two houses of parliament, the federal government," or any of the constituent republics of the federation (Dore 1995, 701). However, there is nothing to suggest that the court has the power to review or otherwise modify presidential pardons. Moreover, the court now consists of Yeltsin appointees who are mindful of the fact that Yeltsin had disbanded the previous court. They have generally been very cautious about challenging presidential prerogatives (Parrish 1998).

Legislative Action. The constitution of 1993 stipulates that Russia shall have a bicameral Federal Assembly consisting of a lower house State Duma elected by the people to four-year terms - half by proportional representation and half in single-member district races - and an upper house Federation Council constituted of two members from each region. Neither collectively nor individually can either body check the president's pardoning power. 
There is, however, an indirect means by which that power may be mitigated, at least in a positive sense. Article 103[f] of the Constitution states that "the jurisdiction of the State Duma shall include ... granting amnesty." It is the nature and use of this power of the Duma that will be taken up here. As noted, previous Soviet and Russian constitutions were somewhat ambiguous in the allocation of the power to grant pardons and amnesties. The present constitution is very clear: the president pardons and the Duma grants amnesty not subject to presidential veto. Unlike arrangements in some other constitutional democracies, the Duma does not share this power with the upper house of the legislature (Barry 1994). One possible explanation for this is that the provision was crafted such that the Duma would enhance its ability to serve as a counterweight to a super-presidential constitutional arrangement. Yet, more probably, "amnesty power was not seen as a function of great significance, and giving it to the State Duma was in reality a token gesture" (Barry 1994, 450). Its recent use, however, suggests that it is more than simply a "token" power. Since 1994, the Duma has granted several highly controversial amnesties. All serve to highlight the fact that while the president's power to pardon is absolute, the Duma can also dispense, unchecked, its own version of justice.

The first and perhaps most dramatic case of legislative amnesty came in early 1994, shortly after the first Duma was seated. Although voters ratified Yeltsin's Constitution in December, they also elected a rather combative opposition Duma. In February 1994, as one of their first orders of business, they overwhelmingly approved a resolution granting amnesty to the leaders of the October insurrection as well as to those hard-line Communists who were facing trial for their role in the failed coup of August 1991 against then-Soviet president Mikhail Gorbachev. Yeltsin, clearly opposed to the move, attempted to argue that the Duma was exceeding its authority by replacing pardoning with amnesty, but to no avail. The president's argument rested on the idea that amnesty is reserved for those already convicted of a crime (Bohlen 1994). To his credit Yeltsin did nothing, but there was little to do; under the Russian Constitution, amnesty is granted by way of a Duma resolution, not law, and thus is not subject to presidential veto (Goldberg 1994).

Another notable use of legislative amnesties was during both Chechen Wars. In December 1994, Russia began what proved to be an ill-fated and highly unpopular military campaign against the breakaway Republic of Chechnya. As a part of the peace process, from early January 1995 through 
Presidential Power Unbound 225

June 1998, the Duma discussed and passed, often without respect to Yeltsin's stand, resolutions granting amnesties to several individuals and classes of individuals involved in the war. These included the Chechen rebels themselves, the perpetrators of the kidnappings in Budennovsk (June 1995) and Kizlyar-Pervomaiskoe (January 1996), separatist Chechen President Dzhokhar Dudaev, Chechen Prime Minister Shamil Basaev, and deserters from the Russian army. ${ }^{12}$ Debate over these resolutions was highly charged. A second military campaign in the troubled republic was begun in September 1999 as the result of Chechen aggression in the neighboring Republic of Dagestan and several apartment bombings in Russia. Perhaps because this campaign seemed to be more successful, the Russian Duma easily passed a bill granting amnesty to all Chechen fighters who surrendered by February 1, 2000 (OMRI, November, 13, 1999; January 31, 2000).

There have been other, less controversial amnesties granted by the Duma since 1994. Mainly, these have dealt with prisoners of Russia's overcrowded, under-funded, and disease-ridden prison system, which has attracted the attention of human rights groups worldwide. In April 1995, they voted to release some 30,000 prisoners to mark the 50th anniversary of the Allied victory in World War II (celebrated in Russia on May 9). ${ }^{13}$ At Yeltsin's urging, the Duma granted full or partial amnesties to another 445,000 convicted criminals as an "humanitarian act" in late 1997. A similar resolution passed in December 1998 and in 1999. ${ }^{14}$

As in the United States, the formal checks on presidential pardon power in Russia are limited. Again, constitutional design and the separation of powers it establishes are the source of the virtually unchecked nature of this presidential power. An independent judiciary, still in its infancy in Russia, is powerless to overturn presidential pardons. The Russian Constitution is exceptionally difficult to amend, and it is highly unlikely that the presidential pardoning power would be the object of proposed amendments in any case. However, in Russia, while the legislature cannot check the president's pardoning power, it can preempt his use of the power by way of its constitutional power of amnesty. This power can and has been used to affect public policy often contrary to the president's preferences: settling scores with a past regime, peace negotiations, and criminal justice policy. 


\section{Conclusions}

Several points are worth highlighting in the comparison between presidential pardons in the United States and Russia. The Russian case highlights the fine line between a pardon and an amnesty. For example, immediately after Moskovskii Komsomolets journalist Vadim Poegli was sentenced for "insulting" then Defense Minister Pavel Grachev in print, the Duma granted him amnesty, in effect pardoning him. Conversely, Yeltsin had considered issuing a broad pardon - in effect, an amnesty - for many of the participants in the 1991 abortive coup before the Duma passed its amnesty resolution. His idea seems to have served as the basis for the subsequent Duma action; many deputies saw the exercising of a broad pardon as infringing on their own amnesty power (Barry 1994, 452). These two examples serve to illustrate the confusion over the seemingly simple notion that pardons are for individuals and amnesties for groups of individuals.

In both the United States and Russia, the pardon power is virtually unchecked by formal constraints. In neither country are there readily available formal measures to limit or overturn the use of pardon power. Constitutional, judicial, and legislative checks are cumbersome and impractical at best in both cases. One possible exception to this is in Russia where legislative amnesty serves as a positive "check" on the presidential power to pardon. There we saw the Duma not only preempting Yeltsin, but in one case going much further in their amnesty resolutions than he intended.

In the United States, except in cases of impeachment, the president's pardon authority has no apparent formal limit. There has even been speculation that a president could pardon himself. Former Nixon Chief of Staff Alexander Haig writes in his autobiography that one of the legal options given to President Nixon prior to his resignation was to pardon himself and then resign (Haig 1992, 481). As with any discretionary power, this raises the specter of potential misuse or abuse of pardon authority. This seems particularly problematic in Russia where the president and the legislature both lay claim to this authority.

Media speculation once had President Clinton pardoning his wife, Hillary Rodham Clinton, should she have been indicted for crimes related to her involvement in the Whitewater partnership. It is almost a certainty that the Supreme Court would have been asked to rule had President Nixon pardoned himself. Lacking a case for judicial review, the potential of self- 
Presidential Power Unbound 227

pardon remains only fodder for hypothetical speculation. President Clinton might have faced a similar Supreme Court challenge should he have pardoned his wife. However, judicial rulings to date seem to indicate a constitutional basis for this highly unusual course of action. Of course, the political implications of such a choice are another matter altogether. Public approval remains a powerful informal power of the presidency, and the political capital expended in such an action might make it unpalatable.

It might be speculated that there are a few sources of extra-constitutional influence, or potential influence, on a president's power to pardon. For example, it is easy to imagine that President Clinton would have been especially sensitive to public opinion. In the case of Russia, we saw how foreign pressure from the Council of Europe shaped President Yeltsin's use of the pardon in death penalty cases. These potential sources of pressure also highlight the obvious shortcomings of a strictly formal approach to comparative politics. We can see a vast difference between the stable and well-established pardon power in the United States versus the ongoing struggle to gain control of the pardon power in Russia. With a few notable exceptions, the use of the pardon power in the United States goes relatively unnoticed. The use of pardon authority is quite routinized and stable in the United States, in the main focused on criminal activity and the restoration of civil rights (Brown 1940). This is not the case in Russia. We might attribute the unsettled status of the Russian pardon to both constitutional design and the growing pains of an inchoate democracy. That President Yeltsin and the Russian legislature would engage in a struggle for what is considered to be a relatively unimportant power in the United States suggests that in the new Russian republic there is still a great deal to be settled about the actual division of power between the institutions of government. The Russian case - and early United States history — suggests that pardons for political crimes are more important in less developed states.

That said, it must also be noted that we do see the pardon power being used in both the United States and Russia as Alexander Hamilton had suggested over two hundred years ago, to quell "seasons of insurrection or rebellion" (Federalist 74). Whether the insurrection is a large-scale putsch in Russia or an attempt to heal a nation following the resignation of a controversial president in the United States, a timely pardon has served the needs of both countries in times of political unrest. In this sense, the power to pardon may be viewed in a broader historical context as an act of grace and forgiveness, as a useful political tool to bring moderation to a sometimes 
intemperate system.

Pardons are thus potentially important in a discussion of what Samuel Huntington has referred to as the problem of "prosecute and punish vs. forgive and forget" in his discussion of "crimes" of the previous regime in transitions to democracy (1991, 211-31). Although Huntington does not mention it directly, it might be that pardons represent a politically temperate middle ground and a great aid in the transition itself. One of the tasks in a transition is to provide incentives to officials of the authoritarian regime to affect, or acquiesce to, a regime change. Insuring their safety and perhaps immunity might be just the tool for that task. Counter-examples of this might be the "truth and reconciliation" process underway in South Africa or the "Lustration" process - a move to uncover crimes of the former Communist regimes - in Poland and other Eastern European countries. Both of these processes seem more aimed at justice rather than expediency. If this represents an international trend, it could bode ill for future transitions, as a significant incentive for authoritarian leaders to relinquish power would be removed. 


\section{Presidential Power Unbound 229}

\section{Appendices}

Appendix I: Constitutions

Constitutions of the World: http://www.uni-wuerzburg.de/law/

The constitution of Cyprus: http://www.kypros.org/Constitution/English/ appendix_d_part_iii.html

The constitution of Iceland: http://www.urich.edu/ jpjones/confinder/ Iceland2.htm

The constitution of Moldova: http://www.parlament.md/en/ legalfoundation/constitution

The constitution of Portugal: http://www.parlamento.pt/leis/ constituicao_ingles/crp_uk.htm

The constitution of Turkey: http://www.turkey.org/

The constitution of Georgia: http://www.friends-partners.org/oldfriends/ constitution/constitution.georgia.html

Appendix II: Selected Legal Cases

Biddle v. Perovich, 274 U.S. 480 (1927)

Burdick v. United States, 236 U.S. 79 (1915)

Garland, Ex parte, 4 Wallace 333 (1867)

Grossman, Ex parte, 267 U.S. 87 (1924)

Murphy v. Ford, 390 F. Supp. 1272 (1975)

Wells, Ex parte, 15 L.Ed. 421, 423 (1855) 


\section{Notes}

${ }^{1}$ The Bosnian Constitution makes no mention of the pardon power. See Appendix I for a list of constitutional sources.

${ }^{2}$ In the United States, general amnesty grants are often issued following military conflicts and may be viewed as a remedy for "political" crimes. For example, Presidents Lincoln and Johnson offered an extensive amnesty program following the Civil War, as did Presidents Ford and Carter following the Vietnam War. Similarly, President Washington issued a "collective" pardon after the "Shays" Rebellion (in fact, the United States' Constitution does not mention the word amnesty).

${ }^{3}$ Interview with Hope P. McGowan, attorney in the OPA.

${ }^{4}$ Because pardon application files are created for advisory purposes they may be exempt from Freedom of Information Act requests. This creates one hurdle for detailed research into the administrative aspects of the pardon process.

${ }^{5}$ Data prepared by the Office of the Pardon Attorney, July 14, 2000.

${ }^{6}$ See Morris (1998) for a more detailed review.

${ }^{7}$ A total of four constitutions governed Russia and the Soviet Union until 1991, the 1918 Constitution of the Russian Soviet Federated Soviet Republic (RSFSR), and the 1924, 1936, and 1977 constitutions of the Union of Soviet Socialist Republics (USSR). The 1918 and 1924 constitutions did not mention pardons, vesting amnesty powers to the legislature. The 1936 Constitution granted the power to pardon to the Presidium of the USSR Supreme Soviet, which in practice also exercised amnesty power. The 1977 Constitution gave the Presidium both amnesty and pardon power. (1918 RSFSR Constitution, Article 49[q], Unger, 1982:33; 1924 USSR Constitution, Article 1[v], ibid.:62; 1936 USSR Constitution, Article 14[w], 30, and 64, Article 49[h], ibid.:142-44, 146, 148; the 1977 USSR Constitution, Article 121[11], ibid.:256). Of course the formal division of state power meant little in the USSR, as final authority rested with the Communist Party (Jacobs, 1983).

${ }^{8}$ Roughly a hundred people died in fighting; see White et al. (1997, 92-4).

${ }^{9}$ Official reports state that just over 50 percent of the eligible voting population turned out, but there is good reason to believe that this figure was doctored (White et al., 1997, 126). 


\section{Presidential Power Unbound 231}

${ }^{10}$ Specifically, Protocol 6 of the European Convention on Human Rights.

${ }^{11}$ Some human rights activists have disputed this claim (OMRI, September 4, 1997).

${ }^{12}$ See OMRI, January 10, April 6\&20, and June 16\&29, 1995; February 12, March 14, April 2, and October 25, 1996; January 10, February 7\&10, March 7, 10\&12, and May 30, 1997; February 2, March 5\&27, and June 29, 1998.

${ }^{13}$ Not unlike the practice of celebrating holidays in the old USSR, as well as in other countries.

${ }^{14}$ See OMRI, April 20, 1995; August 21, 1997; December 4\&30, 1997; 7 August 7\&18, 1998; February 1, 1999; June 14, 1999. 
References

August, Marilyn. 2000. "Ex-nazi Collaborator's Pardon Plea Denied." March 7, 2000. Online at http://www.sun-sentinel.com/news/daily/ detail/0,1136,29000000000108034,00.html

Barry, Donald D. 1994. "Amnesty Under the Russian Constitution: Evolution of the Provision and Its Use in February 1994." Parker School Journal of East European Law 1 (4): 437-61.

Baylis, Thomas. 1996. "Presidents versus Prime Ministers." World Politics 48 (3): 297-323.

Belin, Laura. 2000. "The Yeltsin 'Family' Triumph." Online at http:// www.tol.cz/countries/rusar99.html.

Brown, Everett S. 1940. "The Restoration of Civil and Political Rights by Presidential Pardon." American Political Science Review 34 (2): 295-300.

Carey, John M., and Mathew Soberg Shugart. 1998. Executive Decree Authority. Cambridge, JK: University of Cambridge.

Charlton, Angela. 1999. "Yeltsin Commutes All Death Sentences in Russia." Nando Media. June 4, 1999. Online at http:// www.nando.net/noframes/story 0,2107,56012-89476-636103-0,00.html.

Colton, Timothy J., and Robert C. Tucker, eds. 1995. Patterns in Post-Soviet Leadership. Boulder, CO: Westview.

"Constitution of the Russian Federation." 1993. Online at http:// www.departments.bucknell.edu/russian/index.html.

Dore, Isaak I. 1995. "The Distribution of Governmental Power Under the Constitution in Russia." Parker School Journal of East European Law 2 (6): 673-705. 


\section{Presidential Power Unbound 233}

Elster, Jon. 1997. "Afterward: The Making of Postcommunist Presidencies." In Postcommunist Presidencies, edited by Ray Taras. Cambridge, UK: Cambridge University.

Frye, Timothy. 1997. "The Politics of Constitutional Choices: Post-Communist Presidencies." Comparable Political Studies 30: $523-52$.

Goldberg, Carey. 1994. "Legislators Pardon Yeltsin Opponents." The New York Times. February 24, 1994. p.A1.

Gray, Malcolm. 1998. "Russia: 11 Months, 26, 862 Murders." The Ottowa Citizen. December 26, 1998. p.B4.

Haig, Alexander M., Jr., with Charles McCarry. 1992. Inner Circles: How America Changed the World, A Memoir. New York: Warner Books, Inc.

Halperin, Rick. 1999. "Death Penalty News C Worldwide.” February 13, 1999. Online at http://venus.soci.niu.edu/ archives/ABOLISH/ jan99/1094.html.

Hamilton, Alexander, James Madison, and John Jay. 1961. The Federalist Papers. New York: Mentor Books.

"Have Passports, Will Travel.” The New York Times. October 29, 1994. Sports Desk, p. 29.

Holmes, Stephen. 1993. "Superpresidentialism and its Problems." East European Constitutional Review 2 (4), 3 (1): 123-6.

Humbert, W. H. 1941. The Pardoning Power of the President. Washington, D.C.: American Council On Public Affairs.

Huntington, Samuel P. 1991. The Third Wave: Democratization in the Late Twentieth Century. Norman, OK: University of Oklahoma. 
"King Grants Pardon to 1,807 Convicts." July 9, 1999. Online at http:// www.arabicnews.com/ansub/Daily/Day/990709/1999070926.html.

King, Anthony. 1993. Foundations of Power. In Researching the Presidency: Vital Questions, New Approaches, edited by George C. Edwards III, John H. Kessel, and Bert A. Rockman. Pittsburgh: University of Pittsburgh.

Lijphart, Arend, ed. 1992. Parliamentary Versus Presidential Government. Oxford, UK: Oxford University Press.

Linz, Juan J. 1990. "The Perils of Presidentialism.” Journal of Democracy 1: 51-69.

Linz, Juan J., and Arturo Valenzuela. 1994. The Failure of Presidential Democracy, vol. 1-2. Baltimore: Johns Hopkins University Press.

Lucky, Christian. 1993. "A Comparative Chart of Presidential Powers in Eastern Europe." East European Constitutional Review 2 (4), 3 (1): 81-94.

MacGregor, James. 1994. "The Presidency in East Central Europe." RFE/RL Research Report 3 (2): 23-31.

Moore, Kathleen Dean. 1989. Pardons: Justice, Mercy, and Public Interest. New York: Oxford University.

Naravane, Vaiju. 2000. "Italy Grants Clemency to Papal Assailant." June 15, 2000. Online at http://www.indiaserver.com:80/thehindu/ 2000/06/15/stories/0315000i.htm

O’Donnell, Guillermo. 1995. "Delegative Democracy." Journal of Democracy. 5 (1): 55-69.Open Media Research Institute Daily Digest. Online at http://www.rferl.org.

Parrish, Scott. 1998. "Presidential Decree Authority in Russia, 1991-95." In Executive Decree Authority, edited by John M. Carey and Matthew Soberg Shugart. Cambridge, UK: University of Cambridge. 
Presidential Power Unbound 235

Przeworski, Adam, Michael Alvarez, Jose Antonio Cheibub, and Fernando Limongi. 1997. "What Makes Democracies Endure?” In Consolidating the Third Wave Democracies, edited by Larry Diamond, et al. Baltimore: John Hopkins.

Renfrew, Barry. 2000. "Yeltsin Quits, Is Granted Immunity." January 1, 2000. Online at http://www.drumcorp.com/wwwboard/ messages/89.html.

Reynolds, Maura. 1998 “The Death Penalty: Russia.” February 8, 1998. Online at http://1vrj.com/lvrj_home/1998/Feb-08-Sun-1998/news/ 6919297.html.

Riggs, Fred. 1988. The Survival of Presidentialism in America: Para-constitutional Practices. International Political Science Review 9 (4): 247-78.

Shugart, Matthew S., and John M. Carey. 1992. Presidents and Assemblies: Constitutional Design and Electoral Dynamics. Cambridge, UK: Cambridge.

Stepan, Alfred, and Cindy Skach. 1996. "Constitutional Frameworks and Democratic Consolidation: Parliamentarianism and Presidentialism." World Politics 46 (1): 1-22.

Strøm, Kaare, and Octavio Amorim Neto. 1999. "Duverger Revisited: Presidential Power in European Parliamentary Democracies." Paper presented at the Annual Meeting of the American Political Science Association, Atlanta, GA, September 2-5, 1999.

Taras, Ray, ed.1997. Postcommunist Presidencies. Cambridge, UK: Cambridge University Press.

White, Stephen, Richard Rose, and Ian McAllister. 1997. How Russia Votes. Chatham, NJ: Chatham House. 
Wohlwend, Renate. 1997. "Report: Honouring of the Commitment Entered into by Russia upon Accession to the Council of Europe to Put into Place a Moratorium on Executions of the Death Penalty." Document 7746. January 28, 1997. Online at http://stars.coe.fr/ ,edoc7746.html. 
